\title{
Vitamin D Deficiency as a Risk Factor in Non-Squamous Lung Cancer Subgroups - A Preliminary Study
}

\author{
Ahmet Bulent Kargi ${ }^{1 *}$, Meltem Demir ${ }^{2}$, Ezel Tasdemir ${ }^{3}$, Aysegul Kargi ${ }^{4}$ \\ ${ }^{1}$ Department of Thoracic Surgery, Medicalpark Hospital Antalya, Turkey \\ ${ }^{2}$ Department of Biochemistry, Medicalpark Hospital Antalya, Turkey \\ ${ }^{3}$ Department of Internal Medicine, Medicalpark Hospital Antalya Turkey \\ ${ }^{4}$ Department of Medical Oncology, Medstar Hospital Antalya Turkey
}

\begin{abstract}
Background: It has been known that smoking is the primary causative factor of lung cancer, but other factors also play roles. Epidemiological studies demonstrate an increase of cancer in people lower exposure to sunlight and which has an impact in the synthesis of active $25(\mathrm{OH}) \mathrm{D}$. The aim of study was to determinate the potential role of $25(\mathrm{OH}) \mathrm{D}$ etiologic factor in subtypes of lung cancer.
\end{abstract}

Methods: There were 140 participants of which 100 were men $(71.4 \%)$ and $40(28.6 \%)$ were women. The study group was 60 lung cancer before any treatment participants (48 male, 12 female) and control group was 80 (52 male, 28 female). The study group was divided into three histologic subtypes; small cell lung cancer (SCLC) (13 pts, $21.7 \%$ ), squamous cell lung cancer (SqCC) (18 pts, 30\%) and non-squamous (23 adenocarcinoma, 6 others; total 29 pts, $48.3 \%)$

Results: There was significant difference between smoking and histologic subgroups $(p<0.001)$. While the SCLC $(p=0.002)$ and the SqCC $(p<0.001)$ group had a significantly more pack/year smoking; no difference in non-squamous subgroup $(p=0.114)$. $25(\mathrm{OH}) \mathrm{D}$ levels was significantly less in non-squamous cell subgroups $(p<0.001)$. Smoking group has less $25(\mathrm{OH}) \mathrm{D}$ levels than non-smoker group significantly $(p=0.006)$.

Conclusion: Meanwhile smoking is a risk factor for SCLC and SqCC; in non-squamous subtype 25(OH)D deficiency could be a causative factor. Our findings may be supported with further studies including larger patient populations.

Keywords: Vitamin D deficiency; $25(\mathrm{OH}) \mathrm{D}$; Cancer; Smoking; Non-squamous cell carcinoma; Lung cancer

\section{Introduction}

Lung cancer is the leading cause of cancer mortality in both men and women, and it has been known for decades that smoking is the primary causative factor [1]. However, lung cancer does not develop in all smokers and can occur in non-smokers as well, suggesting that other factors can play a role in the development of lung cancer [2]. Largescale epidemiological studies have demonstrated an increase in some types of cancer in individuals who live in high-altitude countries and have lower exposure to sunlight $[3,4]$. Because the ultraviolet $B$ beams in natural sunlight play a role in the synthesis of active vitamin $D$, researchers have focused on the role of 25-hydroxyvitamin D3 $(25(\mathrm{OH})$ D) in cancer development [5]. In the last decade, the relationship between $25(\mathrm{OH}) \mathrm{D}$ and many different types of cancers, including breast, pancreas, colon and prostate, has been shown $[4,6]$. The aim of this preliminary study was to determinate the role of $25(\mathrm{OH}) \mathrm{D}$ as an etiologic factor in subgroups of lung cancer.

\section{Methods}

From January 2008 to December 2014, 140 participants, of whom 100 were men $(71.4 \%)$ and $40(28.6 \%)$ were women, were entered into the study. The study group, which comprised participants who had been diagnosed with lung cancer, contained 60 individuals (48 males and 12 females), and the control group contained 80 individuals ( 52 males and 28 females). Blood samples were collected from newly diagnosed lung cancer patients prior to any treatment. The control group consisted of well-matched individuals whose $25(\mathrm{OH}) \mathrm{D}$ levels were measured for other reasons. Participants who had been diagnosed with any other type of cancer, chronic kidney disease, stem cell transplant recipients and, who had been given $25(\mathrm{OH}) \mathrm{D}$ treatment or whose specimens had hemolysis prior to analysis were excluded from the control group.

Age, sex, smoking status, serum 25(OH)D levels and cancer type were also recorded for the study group. For participants who were smokers, the pack-years of cigarette smoking were recorded as the year. The study group was divided into three histologic subgroups: small cell lung cancer (SCLC) (13 patients, 21.7\%), squamous cell lung cancer (SqCC) (18 patients, 30\%) and non-squamous non-small cell lung carcinoma (23 adenocarcinoma, 4 large cell, 1 sarcomatoid and 1 neuroendocrine; a total of 29 patients; $48.3 \%$ ).

Venous blood samples were obtained after an overnight fast, and samples underwent centrifugation at $1,500 \mathrm{rpm}$ for 5 minutes and were stored at $-70^{\circ} \mathrm{C}$ until the date of analysis. $25(\mathrm{OH}) \mathrm{D}$ was measured using an Architect i2000 automated chemiluminescent immunoassay analyzer (Abbott Laboratories, Abbott Park, IL, USA). 25(OH)D deficiency was defined as a level $<20 \mathrm{ng} / \mathrm{ml}$. The study was approved by the local ethics committee.

*Corresponding author: Ahmet BK, Dept. of Thoracic Surgery Medicalpark Hospital Fener m. Tekelioglu c No: 7, 07200 Antalya, Turkey, Tel: +90242 3143434; Fax: +90242 314 3030; Email: abkargi@hotmail.com

Received April 16, 2016; Accepted May 16, 2016; Published May 20, 2016

Citation: Kargi AB, Demir M, Tasdemir E, Kargi A (2016) Vitamin D Deficiency as a Risk Factor in Non-Squamous Lung Cancer Subgroups - A Preliminary Study. J Clin Respir Dis Care 2: 113. doi: 10.4172/ 2472-1247.1000113

Copyright: @ 2016 Kargi AB, et al. This is an open-access article distributed under the terms of the Creative Commons Attribution License, which permits unrestricted use, distribution, and reproduction in any medium, provided the original author and source are credited. 
Citation: Kargi AB, Demir M, Tasdemir E, Kargi A (2016) Vitamin D Deficiency as a Risk Factor in Non-Squamous Lung Cancer Subgroups - A Preliminary Study. J Clin Respir Dis Care 2: 113. doi: 10.4172/2472-1247.1000113

Page 2 of 4

\section{Statistical analysis}

Statistical analysis was conducted using SPSS for Windows software (ver. 20.0; SPSS Inc., Chicago, IL, USA). All statistical tests were performed at the two-sided 0.05 level. A p value less than 0.05 was considered to indicate a statistically significant difference. Demographic and clinical variables were compared using Pearson's chi-square tests for categorical variables, Pearson correlation coefficients to analyze the relation between the dependent variables and Mann-Whitney U tests for continuous variables, where appropriate.

\section{Results}

The study group contained $48(80 \%)$ men and 12 women (20\%), while the control group contained 52 men (65\%) and 28 women (35\%). The mean age of the study group was $60.03 \pm 9.62$ years (range: $38-80$ years) while that of the control group was $59.18 \pm 11.44$ years (range: 32-81 years). There was no statistically significant difference in age $(\mathrm{p}=0.644)$ or $\mathrm{sex}(\mathrm{p}=0.052)$ between the two groups. The percentage of smokers was $78.3 \%$ and $36.3 \%$ in the study and the control group, respectively. However, there was no significant difference in the percentage of smokers between two groups ( $\mathrm{p}>0.05$, Table 1$)$.

Among the pathologic subgroups, SCLC and SqCC have significantly higher amounts of smoking pack per year than control group ( $p=0.002, p<0.001$, respectively). However, there was no significant difference in the amounts of smoking pack per year between non-squamous subgroup and control group ( $p>0.05$, Table 2).

The average level of $25(\mathrm{OH}) \mathrm{D}$ was $15.78 \pm 6.58 \mathrm{ng} / \mathrm{dL}$ and $25.29 \pm$ $12 \mathrm{ng} / \mathrm{dL}$, in the study and control group respectively, with a significant difference between two groups $(p<0.001)$ (Table 3$)$.

There was a significant difference serum 25(OH)D levels in histopathologic subgroups $(\mathrm{p}<0.001)$. In the post-hoc tests, the difference was found between the control and non-squamous group (Table 4). 25(OH)D levels were decreased in non-squamous group than control group significantly $(\mathrm{p}<0.001)$.

The smoking group showed significantly lower vitamin $25(\mathrm{OH})$ $\mathrm{D}$ levels than the non-smoker group $(\mathrm{p}=0.005)$. There was a negative correlation between cigarette smoking and serum 25(OH)D level $(\mathrm{p}<0.001)(\mathrm{r}=-0.305)$ (Figure 1).

\begin{tabular}{|c|c|c|c|c|}
\hline & Non-smoker (\%) & Smoker (\%) & Total (\%) & $\boldsymbol{p}$ \\
\hline Study group & $13(21.7)$ & $47(78.3)$ & $60(100)$ & $>0.05$ \\
\hline Control group & $51(63.7)$ & $29(36.3)$ & $80(100)$ & \\
\hline Total & $64(45.7)$ & $76(54.3)$ & $140(100)$ & \\
\hline
\end{tabular}

Table 1: Cancer and smoking status.

\begin{tabular}{|c|c|c|c|}
\hline & Mean & Std. Deviation & $\boldsymbol{p}$ \\
\hline SCLC & 31,62 & 16,17 & $\mathbf{0 . 0 0 2}$ \\
\hline SqCC & 35,67 & 12,38 & $<\mathbf{0 . 0 0 1}$ \\
\hline NON-SQU & 21,38 & 18,70 & 0.112 \\
\hline Control & 11,31 & 16,87 & \\
\hline
\end{tabular}

SCLC: Small Cell Lung Cancer; SqCC: Squamous Cell Lung Cancer; NON-SQU: Non- Squamous Cell Lung Cancer.

Table 2: Lung cancer subgroups and smoking pack/year

\begin{tabular}{|c|c|c|c|c|c|}
\hline & $\mathbf{n}$ & Vitamin D ng/mL & Std. Deviation & Range & $\boldsymbol{p}$ \\
\hline Study & 60 & 15.78 & 6.58 & $4.9-42.7$ & $<\mathbf{0 . 0 0 1}$ \\
\hline Control & 80 & 25.29 & 12.00 & $8.2-65.92$ & \\
\hline
\end{tabular}

Table 3: Serum 25(OH)D levels and lung cancer.

\begin{tabular}{|c|c|c|c|c|c|}
\hline & $\mathbf{n}$ & $\mathbf{2 5}(\mathbf{O H}) \mathbf{D}$ & Std. Deviation & Range & $\boldsymbol{p}$ \\
\hline SCLC & 13 & 17.54 & 7.22 & $10-34.3$ & 0.058 \\
\hline SqCC & 18 & 17.16 & 5.75 & $5.1-29.9$ & 0.66 \\
\hline NON-SQU & 29 & 14.12 & 6.57 & $4.9-32.7$ & $<0.001$ \\
\hline Control & 80 & 25.29 & 12.00 & $8.2-65.92$ & \\
\hline
\end{tabular}

SCLC: Small Cell Lung Cancer; SqCC: Squamous Cell Lung Cancer; NON-SQU: Non- Squamous Cell Lung Cancer.

Table 4: Serum 25(OH)D levels (ng/dL) and lung cancer subgroups.

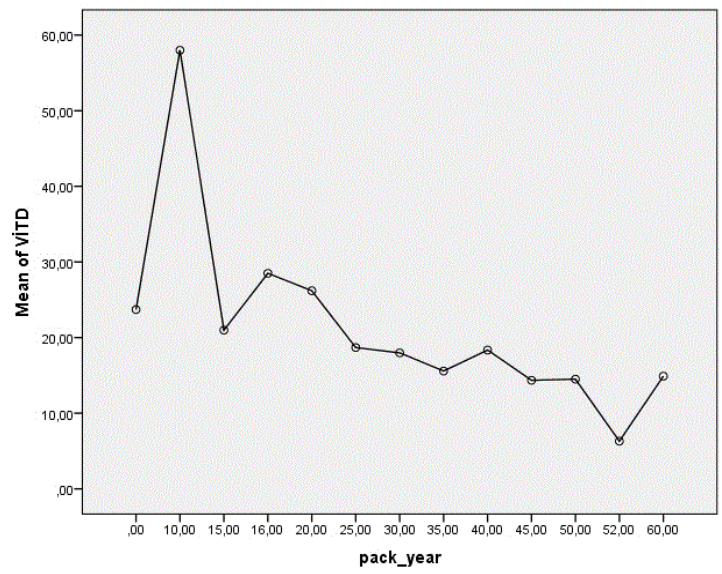

Figure 1: Cigarette smoking amount and serum 25(OH)D levels.

\section{Discussion}

Lung cancer is the leading cause of cancer-related deaths in western countries [1]. In Turkey, lung cancer is the second most common type of cancer in men after prostate cancer. It is the second most common type of cancer in women in the US, and the sixth most common cancer in women in Turkey [1,7]. Smoking alone is responsible for $75 \%$ to $85 \%$ of all lung cancer cases [2]. However, as lung cancer does not develop in all smokers, and lung cancer can occur in non-smokers, there must be other factors playing a role in cancer development. Among nonsmokers with lung cancer, $15-25 \%$ shows many etiologic factors, some gene mutations (EGFR, ALK genes), or certain environmental factors, such as radon and asbestos exposure [8].

Since the 1940s, it was observed that individuals living at higher latitudes, who have lower exposure to sunlight, were at a higher risk of cancer [9]. In 1980, Garland and Garland first proved the association between latitude and colon cancer from 25(OH)D deficiency as a result of reduced sun exposure [4]. Based on those findings, large epidemiological studies have confirmed the importance of $25(\mathrm{OH}) \mathrm{D}$ to cancer risk $(3,6,10)$. In addition to dietary intake, another important determinant of $25(\mathrm{OH}) \mathrm{D}$ levels is exposure to sunlight, which plays an important role in $25(\mathrm{OH}) \mathrm{D}$ synthesis [10].

$25(\mathrm{OH}) \mathrm{D}$ is a steroid hormone that is synthesized in the skin from 7-dehydrocholesterol through solar UV-B exposure, or obtained through dietary sources and supplements. It is metabolized in the liver to make $25(\mathrm{OH}) \mathrm{D}$, and in the kidney to make its active form, 1,25-dihydroxyvitamin $\mathrm{D} 3\left(1,25(\mathrm{OH})_{2} \mathrm{D}\right)[10,11]$.

The hormonal activity of $25(\mathrm{OH}) \mathrm{D}$ is mediated by vitamin $\mathrm{D}$ receptors (VDR) within the nuclei of cells. The active form of $1,25(\mathrm{OH})_{2} \mathrm{D}$ binds to VDRs and, upon ligand binding, dimerizes with the retinoic acid $\mathrm{X}$ receptor [11]. This complex binds to vitamin D-responsive elements 
(VDRE) within the promoter regions of vitamin D-responsive genes causes subsequent changes in the activity of genes involved in cell division, cell adhesion, and other functions [12,13]. Brain, prostate, breast, and colon tissues, as well as immune cells, have vitamin $\mathrm{D}$ receptors and respond to the active form of 1,25(OH)D.

Apart from its primary role in maintaining the homeostasis of calcium and phosphorus, 25(OH)D has many non-skeletal actions in the whole body. Furthermore, autoimmune diseases, cardiovascular diseases, diabetes, schizophrenia, depression, osteoarthritis, and asthma, as well as some types of cancer, are associated with $25(\mathrm{OH})$ D status [14]. 25(OH)D is thought to protect against carcinogenesis by promoting cell differentiation and apoptosis, inhibiting cell proliferation, and modulating inflammation and immunity [15].

The recommended cutoff for $25(\mathrm{OH}) \mathrm{D}$ deficiency is $20 \mathrm{ng} / \mathrm{dL}$ (equivalent to $50 \mathrm{nmol} / \mathrm{L}$ ) in a broad range of epidemiological studies [16]. In our study, we also accepted $20 \mathrm{nmol} / \mathrm{L}$ as the cutoff for $25(\mathrm{OH})$ $\mathrm{D}$ deficiency. While the city in which the study was carried out was on the Mediterranean coast of Turkey, which is sunny for nearly 10 months each year, the participants' average 25(OH)D level was $21.25 \mathrm{ng} / \mathrm{dL}$, and only $43.6 \%$ of participants had levels higher than $20 \mathrm{ng} / \mathrm{L}$.

Pazdiora et al. investigated the 25(OH)D serum levels of 170 patients with different types of cancer ( 28 prostate, 43 breast, 49 colorectal, and 50 lung cancer patients) and 214 healthy individuals used as controls. They found that serum $25(\mathrm{OH}) \mathrm{D}$ levels were significantly lower in the study group than the control group [17]. In our study, the $25(\mathrm{OH}) \mathrm{D}$ levels of the participants with lung cancer were significantly lower than those of the control group ( $\mathrm{p}<0.001)$.

A meta-analysis concerning $25(\mathrm{OH}) \mathrm{D}$ and breast cancer prevention demonstrated a $45 \%$ decrease in breast cancer risk for those in the highest quartile of $25(\mathrm{OH}) \mathrm{D}$ compared with those in the lowest quartile [18].

Despite of these protective effects of vitamin D, International Agency for Research on Cancer (IARC) report on prostate cancer, no protective effect could be determined. Furthermore, polymorphisms of the VDR gene may modify the biological activity of vitamin D, resulting in varying susceptibility to prostate cancer, as well as local metabolism of hormonal $25(\mathrm{OH}) \mathrm{D}$, which seems to play an important role in the development and progression of prostate cancer [19].

Kassi et al. demonstrated a high prevalence of $25(\mathrm{OH}) \mathrm{D}$ deficiency in a young and middle-aged male population. Smoking is a significant determinant of serum $25(\mathrm{OH}) \mathrm{D}$; as smoking increases, $25(\mathrm{OH}) \mathrm{D}$ deficiency occurs more frequently [20]. We also found a negative correlation between cigarette smoking and 25(OH)D level $(\mathrm{p}<0.001)$ $(\mathrm{r}=-0.317)$ (Figure 2). The decrease in 25(OH)D levels in smokers can be explained by two hypotheses: the first one posits that cigarette smoking reduces $25(\mathrm{OH}) \mathrm{D}$, and the second posits that smokers do not pay attention to their eating habits.

In another study, the serum level of $25(\mathrm{OH}) \mathrm{D}$ were compared among the groups of non-smokers and smokers with lung cancer and control group; significant differences were found in $25(\mathrm{OH}) \mathrm{D}$ level among the groups. Interestingly, it was observed that a high intake of vitamin D was associated with a lower risk for non-small cell lung cancer in former smokers [21]. In our study, the level of 25(OH)D in the non-smoker group was significantly higher than that in the smoker group $(\mathrm{p}=0.006)$.

Some previous investigations and meta-analysis suggest an inverse association between serum 25(OH)D and lung cancer risk [21,22],

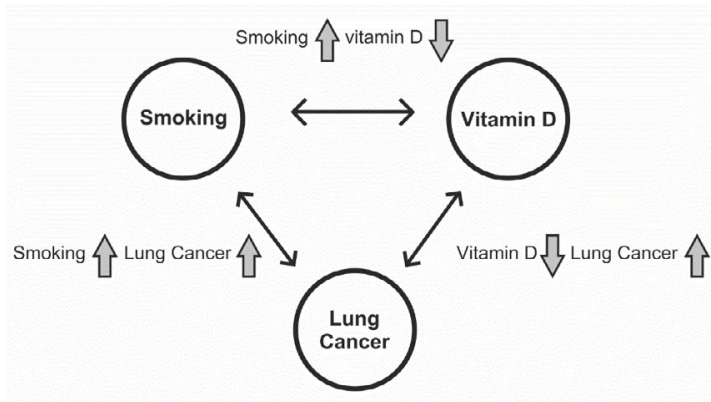

Figure 2: Relationships among smoking, $25(\mathrm{OH}) \mathrm{D}$ level and lung cancer.

however in our study we emphasize on the subtypes of lung cancer. We found a relationship between histopathologic subgroup and $25(\mathrm{OH})$ $\mathrm{D}$ levels in our study $(\mathrm{p}<0.001)$. In the post-hoc tests, a significant difference in the serum levels of $25(\mathrm{OH}) \mathrm{D}$ was found between the control group and the non-squamous group $(\mathrm{p}<0.001)$. It seems that low level of $25(\mathrm{OH}) \mathrm{D}$ is more of a risk factor instead of smoking in the non-squamous group.

Several limitations in this study must be addressed. First, the study used a single-center cohort design conducted on a relatively small scale; thus, replication studies with large, independent cohorts are warranted. Second, we did not detect VDR expression in either serum or cancer tissue. This association should be evaluated in other prospective studies. Furthermore, the potential differences in $25(\mathrm{OH}) \mathrm{D}$ levels between histopathologic subtypes suggested by our study should be examined further.

\section{Conclusion}

Although smoking is an important risk factor for SCLC and SqCC, $25(\mathrm{OH}) \mathrm{D}$ deficiency could be a causative factor for non-squamous subtype of lung cancer. This preliminary study was only a small-scale investigation of the relationship between $25(\mathrm{OH}) \mathrm{D}$ and subtypes of lung cancer however, our findings may be supported with further studies including larger patient populations hence, may provide a guidance for epidemiologic studies.

\section{References}

1. Ferlay J, Shin HR, Bray F, Forman D, Mathers C, et al. (2010) Estimates of worldwide burden of cancer in 2008: GLOBOCAN 2008. Int J Cancer 127: 2893-2917.

2. Thun MJ, Henley SJ, Burns D, Jemal A, Shanks TG, et al. (2006) Lung cancer death rates in lifelong nonsmokers. J Natl Cancer Inst 98: 691-699.

3. Porojnicu AC, Dahlback A, Moan J (2008) Sun exposure and cancer survival in Norway: changes in the risk of death with season of diagnosis and latitude. Adv Exp Med Biol 624: 43-54

4. Garland CF, Garland FC (1980) Do sunlight and vitamin D reduce the likelihood of colon cancer? Int J Epidemiol 9: 227-223.

5. Grant WB (2012) Role of solar UVB irradiance and smoking in cancer as inferred from cancer incidence rates by occupation in Nordic countries. Dermatoendocrinology 4: 203-211.

6. Giovannucci $E$ (2005) The epidemiology of vitamin D and cancer incidence and mortality: a review (United States). Cancer Causes Control 16: 83-95.

7. (2011) Turkish Republic Ministry of Health, Institution of Public Health, Health Statistic Records.

8. Subramanian J, Govindan R (2013) Molecular profile of lung cancer in never smokers. EJC 11: 248-253.

9. Apperly FL (1940) The Relation Solar Radiation to Cancer Mortality in North America. J of Cancer Res 1: 191-196. 
Citation: Kargi AB, Demir M, Tasdemir E, Kargi A (2016) Vitamin D Deficiency as a Risk Factor in Non-Squamous Lung Cancer Subgroups - A Preliminary Study. J Clin Respir Dis Care 2: 113. doi: 10.4172/2472-1247.1000113

10. Holick MF (2014) Cancer, sunlight and vitamin D Review. J of Clin and Trans Endocrinology 1: 179-186.

11. Wacker M and Holick MF (2013) Sunlight and Vitamin D. A global perspective for health. Dermatoendocrinol. 5: 51-108.

12. Kima SH, Chenc G, Kinga AN, Jeona CK, Christensend PJ, et al. (2012) Characterization of vitamin $D$ receptor (VDR) in lung adenocarcinoma. Lung Cancer 77: 265-271.

13. Rukin N, Strange RC (2007) What are the frequency, distribution, and functional effects of vitamin D receptor polymorphisms as related to cancer risk? Nutr Rev 65: 96-101.

14. Makariou S, Liberopoulos EN, Elisaf M, Challa A (2011) Novel roles of vitamin D in disease: What is new in 2011? Eur J Intern Med 22: 355-362.

15. Fleet JC, DeSmet M, Johnson R, Li Y (2012) Vitamin D and cancer: a review of molecular mechanisms. Biochem J 441: 61-76.

16. Choi SW, Kweon SS, Choi JS, Rhee JA, Lee YH, et al. (2015) Estimation of the cutoff value of vitamin D: the Dong-gu study. J Physiol Anthropol 34:10.
17. Pazdiora P, Svobodova S, Fuchsova R, Kucera R, Prazakova M, et al (2011) Vitamin D in colorectal, breast, prostate and lung cancer: a pilot study. Anticancer Res 31: 3619-3621.

18. Chen P, Hu P, Xie D, Qin Y, Wang F, et al. (2010) Meta-analysis of vitamin $\mathrm{D}$, calcium and the prevention of breast cancer. Breast Cancer Res Treat 121:469-477.

19. Grant WB (2009) A critical review of Vitamin D and Cancer: A report of the IARC Working Group. Dermatoendocrinol 1: 25-33.

20. Kassi EN, Stavropoulos S, Kokkoris P, Galanos A, Moutsatsou P, et al. (2014) Smoking is a significant determinant of low serum vitamin $D$ in young and middle-aged healthy males. Hormones (Athens) 14: 245-250.

21. Kilkkinen A, Knekt $P$, Heliövaara M, Rissanen H, Marniemi J, et al. (2008) Vitamin D status and the risk of lung cancer: a cohort study in Finland. Cancer Epidemiol Biomarkers Prev 17: 3274-3278.

22. Zhang L, Wang S, Che X, Li X (2015) Vitamin D and lung cancer risk: a comprehensive review and meta-analysis. Cell Physiol Biochem 36: 299-305. 